\title{
LAS 'LUCES' DE SARA TH***. MARÍA ANTONIA DE RÍO ARNEDO Y SU TRADUCCIÓN DIECIOCHESCA DEL MARQUÉS DE SAINT-LAMBERT
}

\author{
Helena Establier PÉrez
}

El 4 de agosto de 1795, la Gazeta de Madrid anunciaba la reciente traducción de una novela inglesa, Sara $T h^{* * *}$, vertida del francés por Doña María Antonia de Río y Arnedo, y en venta, en sus respectivas ediciones rústica y en pasta, a 3 y 5 reales. Con estas elogiosas palabras recomendaba la Gaceta la lectura de Sara $T h * * *$ :

Esta obrita, apreciable por su sencillez, presenta un modelo de desempeño en las obligaciones de una madre de familia, un exemplo de la felicidad que produce el cumplimiento de ellas, y una pintura agradable de las delicias de la vida del campo (p. 828).

Se trataba, aparentemente, de una loa inocua de los placeres de la vida familiar y campestre, con un toque moralizante y perfectamente coherente con el modelo femenino y la ética social de la España dieciochesca. Lo que el anuncio no decía, como tampoco lo señalaba la portada del libro, era que se ofrecía a los lectores la primera traducción al español de una obra del Marqués Jean-François de Saint-Lambert (1716-1803), filósofo y poeta, enciclopedista, materialista confeso y sospechoso de ateísmo; tampoco se dejaba entrever en ningún lugar que el fondo ideológico de la novela original era bastante más arriesgado que esa idílica instantánea familiar y rural que ofrecía la reseña, ni que la traductora había tenido que emplearse a fondo para brindar una versión algo más «española» $\mathrm{y}$ «femenina» de una obra como ésta, viable en el contexto axiológico de la Francia prerrevolu- 
cionaria, pero inadmisible en la España vigilante e inflexible del cambio de siglo, menos aún en la pluma de una mujer.

De hecho, traducir desde la condición de mujer era tarea delicada en el XVIII español. Ya sabemos, a tenor de las recientes investigaciones sobre la literatura escrita por mujeres en el periodo de la Ilustración española, que el elenco de novelistas dieciochescas no es excesivamente amplio en nuestro país ${ }^{1}$, y también que apenas ninguna de las escritoras que eligen la novela para introducirse en el círculo literario español del cambio de siglo, predominantemente masculino y marcado por la ideología patriarcal, se atreve a dejar en él sus huellas de mujer a través de la creación original ${ }^{2}$. En su lugar, la traducción se contempla, por parte de las mismas escritoras y especialmente de las instituciones dieciochescas que velan por el buen orden moral y social, como una adecuada solución de compromiso, ideológicamente menos arriesgada que la creación propia, ante las cada vez mayores demandas femeninas de acceso al mundo de las letras en nombre del axioma ilustrado sobre la universalidad de la razón. Esta orientación de la pluma femenina hacia la traducción se enmarca en una tendencia general de la novela española de entresiglos, caracterizada, como ya sabemos, por una febril actividad traductora que alcanza su máximo apogeo en la década de los noventa, y que culmina en 1799 con la tajante prohibición del Consejo de Castilla de publicar relatos de ficción ${ }^{3}$.

Antes de que el citado veto a las novelas, de consecuencias devastadoras para el género, se llevara a efecto, la traducción -especialmente de originales franceses- se había convertido en práctica habitual entre los escritores españoles y algunas féminas que se dedicaban a tales menesteres en

1. Son imprescindibles al respecto los trabajos de C.Sullivan (1997), $M^{a} J$. García Garrosa (1998), $\mathbf{M}^{\mathrm{a}}$ del P. Zorrozua (1999), E.Palacios Fernández (2002), E. Fraklin Lewis (2004) y V. Trueba (2005). Todos ellos se encuentran recogidos en la bibliografía final.

2. Sólo Clara Jara de Soto publica una novela original, El instruido en la Corte y aventuras del estremeño (1789), aún en la línea satírico-moral del siglo anterior y de la primera mitad del XVIII. A la segunda parte de la misma, Tertulias murcianas, le fue denegada la licencia de impresión en 1790. El resto de escritoras se inclina por la traducción de novelas, con mayor o menor índice de aportaciones personales, textuales (modificaciones, supresiones y adiciones al original) o extratextuales (digresiones en forma de prólogo, apéndice o notas al pie), según era habitual en el concepto y la práctica dieciochescos de la traducción.

3. Recordemos que aunque la censura, civil y religiosa, venía vapuleando al género novelístico desde mitad de la centuria, es el 27 de mayo de 1799 cuando el Consejo de Castilla dispone que no se admitan más instancias de solicitud de licencia de impresión, y así se lo comunica al Juez de Imprentas y a los escribanos de la Sala de Gobierno. A partir de entonces y hasta 1808, no se admitirán más que reediciones de obras clásicas o modernas, pero en una proporción bajísima; de hecho, en esos nueve años, sólo diez solicitudes serán aceptadas, denegándose todas aquellas relacionadas con la literatura sentimental o melodramática, bajo el pretexto de su escasa utilidad moral o su falta de mérito artístico (Domergue, 1985: 490-1). 
su tiempo de ocio ${ }^{4}$. De hecho, después de los textos de temática religiosa, que ocupan cuantitativamente el primer lugar entre los traducidos del país vecino, y del conjunto de tratados franceses sobre educación y moral, son las narraciones las que atraen mayoritariamente la atención de los traductores españoles ${ }^{5}$. En general, la narrativa francesa de orientación pedagógica y moral, con un componente novelesco en ocasiones francamente escaso, fue muy del agrado de las instancias censoras pertinentes y gozó también de una extraordinaria acogida entre el público español, pues venía oportunamente a satisfacer sin riesgo alguno las inquietudes lectoras de las mujeres, que se incrementaban al mismo tiempo que lo hacía su interés por tomar la pluma, y servían también de acicate para éste. Por su carácter ejemplar y su defensa de una moral sostenida en la religión, las obras de Fénelon, Baculard D'Arnaud, Mme, Le Prince de Beaumont, la Condesa de Genlis, el abate Prévost, Florian, Saint-Pierre, Ducray-Duminil, Mme. de Graffigny, la Marquesa de Lambert, Laplace o Mme. D’Épinay, son algunas de las elegidas por los traductores de nuestro país en las dos últimas décadas del siglo, y muy especialmente por nuestras traductoras, aunque las firmas femeninas al pie de estas versiones sigan siendo escasas en torno al cambio de centuria ${ }^{6}$.

4. Muy pocas escritoras dieciochescas le dieron un enfoque profesional a la escritura o desarrollaron su actividad literaria de forma constante durante toda su vida. La dramaturga malagueña María Rosa Gálvez es un caso excepcional de insistencia voluntariosa en ganarse un lugar destacado en el Parnaso español, y de entender su producción dramática como medio de subsistencia. Escribió cinco comedias y ocho piezas de teatro trágico; logró representar cinco de todas ellas, y publicó conjuntamente la mayor parte de su poesía y su producción dramática en Obras Poéticas (1804).

5. Aurora Aragón, en su estudio sobre las traducciones de obras francesas anunciadas en la Gaceta de Madrid entre 1790 y 1799, ofrece la siguiente distribución: 109 obras religiosas, 38 textos narrativos, 24 de ciencia y 23 de tipo técnico, 19 de historia, 16 de sociedad, 16 obras teatrales, 15 de medicina, 14 de moral, 12 libros de pensamiento, 9 de educación y 6 de poesía. (pp. 262-263). Por su parte, en su Esbozo de biblioteca de la juventud ilustrada, Paula de Demerson deja claro el elevadísimo componente pedagógico y moral de las lecturas destinadas a los jóvenes de su tiempo, las cuales son en gran proporción traducciones del francés.

6. Además de las traducciones de la propia Ma Antonia de Río (Sara Th*** de Saint-Lambert en 1795, y las Cartas de Madame de Montier a su hija de Mme. Le Prince de Beaumont en 1796), Doña Cayetana de la Cerda traduce en 1781 las obras -más tratados morales que otra cosa- de la Marquesa de Lambert, María Romero Masegosa vierte al español la novela epistolar Cartas de una peruana (1792) de Madame de Graffigny, Inés Joyes y Blake traduce la novela filosófica de Samuel Johnson Historia de Rasselas, príncipe de Abisinia (1798), y Rita Caveda trae al español las educativas Cartas selectas de una señora a una sobrina suya entresacadas de una obra inglesa impresa en Filadelfia (1800). Ya traspasada la frontera del nuevo siglo, $\mathrm{M}^{\mathrm{a}} \mathrm{Jacoba}$ Castilla publica la novela moralizante Adelayda o el triunfo del amor (1801) de Mme. de Genlis, Juana Bergnés traduce la novela inglesa Lidia de Gersin (1804) a partir de la versión francesa de Laplace, y también Flora o la niña abandonada (1807) de Elisabeth Sommerville a partir de una versión francesa 


\section{JeAN-FrançoIs De SAINT-LAMbERT Y LOS FILÓSOFOS FRANCESES EN ESPAÑa}

Evidentemente, no todas las obras narrativas francesas lograron encontrar su versión española. La amenaza censora que planeaba permanentemente sobre las publicaciones españolas, impidió que ciertos textos del país vecino -obviamente los de ideología revolucionaria, pero también los de contenido filosófico, inspiración laica o moral relajada- llegaran en traducción a manos de nuestros lectores, que hubieron de contentarse las más de las veces con el mercado clandestino de libros prohibidos en versión original.

Entre ellos, los «filósofos» y «enciclopedistas» franceses fueron proscritos con auténtica virulencia por las instancias censoras españolas, llegando a constituir el principal enemigo de la cruzada inquisitorial a partir de la mitad del siglo, cuando ya comenzaba a desinflarse el combate contra las tesis jansenistas y galicanas que había presidido las primeras décadas de la centuria. La literatura «filosófica» y la novelística impregnada de filosofismo ocuparán, a partir de ese momento, el primer puesto en los edictos inquisitoriales, llegando a 500 los títulos franceses condenados entre 1747 y 1807, con especial recrudecimiento de la vigilancia después de 1789 (Defourneaux, pp. 53 y 137).

Las obras de Rousseau, por ejemplo, fueron condenadas por la Inquisición tan pronto como el éxito del autor comenzó a extenderse por Francia y por toda Europa en la década de los cincuenta, y sus traducciones al español fueron especialmente tardías ${ }^{7}$. Algo similar ocurre con Voltaire, cuyas obras, prohibidas in totum desde 1762, son las que aparecen con mayor frecuencia en los edictos inquisitoriales españoles, o con Diderot, cuya Enciclopedia fue vetada en 1759 , poco tiempo después de que su permiso de publicación fuera revocado en París, mientras que Les bijoux indiscrets y Pensées philosophiques lo fueron en 1766. Aunque una gran parte de las piezas dramáticas de estos autores sí encontró traducción al español, con más o menos vicisitudes a la hora de su aprobación por la censura, no fue pareja la suerte que corrieron sus textos en prosa, filosóficos y narrativos, lo cual se explica posiblemente atendiendo a la autocensura a la que se sometían los traductores españoles para sortear las trabas en el proceso de publicación de sus versiones ${ }^{8}$. Los casos de Voltaire y Diderot son buenos

de Bertin, y Cayetana Aguirre y Rosales vierte al español Virginia, la doncella cristiana (1806) de Michel-Ange Marin, cuyo componente novelesco es nulo.

7. El edicto de 1764 condena a Rousseau «in totum» y prohibe Émile y La Nouvelle Héloïse (Lettres de deux amants). Por su parte, Lettres écrites de la montagne, publicado en 1764, fue prohibido en España en 1766, incluso antes que en Roma (Domergue, 1981, pp. 43-45).

8. En su prolijo estudio sobre la recepción de Voltaire en España, Lafarga(1982) muestra que las obras dramáticas, con las que el escritor alcanzó el triunfo literario en Francia, lograron en España un 
ejemplos del comportamiento de las letras españolas (traductores, críticos, censores, etc.) ante la obra de algunos de los escritores franceses del período prerrevolucionario proscritos en España, cuyas obras puramente literarias sortean la censura y encuentran su lugar en el panorama literario español, mientras que sus composiciones de contenido filosófico y político son consideradas subversivas, y por tanto ignoradas por los traductores o rechazadas por los críticos afines al régimen y por las instancias censoras pertinentes ${ }^{9}$. Las novelas consideradas «filosóficas» y, en general, las obras sospechosas de tolerantismo religioso corren idéntica suerte, como Le Philosophe anglais de Prévost, el Bélisaire de Marmontel o Lettres péruviennes de Mme. de Graffigny, prohibidas respectivamente en 1756, 1779 y 1796.

Pese a todo lo señalado acerca de las dificultades que encontraron las obras en prosa de estos escritores y filósofos galos para ser traducidas en nuestro país, de lo que no cabe ya la menor duda es de que la mayoría de estos textos ideológicamente «sospechosos» fue leída en versión original,

papel destacado en el campo de la traducción de piezas francesas, y constituyen el género cultivado por Voltaire de mayor difusión en nuestro país. Sólo dos fueron condenadas -y tardíamente-por el Santo Oficio: La mort de César (1796) y Mahomet (1805). Para un seguimiento detallado de la fortuna de las traducciones al español de las obras dramáticas del autor francés, demasiado extensa para abordarla aquí, conviene consultar las páginas 122-174 del citado estudio de Lafarga.

Casi todas las obras en prosa de Voltaire, sin embargo, se traducen ya en el XIX: entre las filosóficas, el Ensayo sobre las costumbres y espíritu de las naciones aparece en español en 1827 y la Filosofía de Voltaire en 1822. Respecto a su obra narrativa, las Novelas de Voltaire, traducidas por J.Marchena, se imprimen en Burdeos en 1819, aunque algunas traducciones de novelas sueltas habían aparecido ya con anterioridad, como Zadig, en 1804, o Cándido o El Optimismo, en traducción de Moratín (¿1814?), que sin embargo permaneció inédita hasta 1838.

Respecto a Diderot, encontraron edición dieciochesca sus comedias El hijo natural o Pruebas de la virtud, traducida por Bernardo de Calzada en 1787, y El padre de familias, en la versión de Lorenzo de Villarroel, Marqués de Palacios, de 1785. Sus obras en prosa, no obstante, corrieron diferente suerte. Además de la citada Enciclopedia, en 1761 se prohíbe Bijoux indiscrets, en 1766 Pensées philosophiques, y en 1807 sus Obras Completas, publicadas en Londres en 1773. Casi todas las traducciones de obras en prosa de Diderot se publican en el XIX (como su novela $\mathrm{La}$ Religiosa, en 1821, o sus Obras filosóficas) o ya en el XX (Los dijes indiscretos (1911), Jaques el fatalista (1971), El sobrino de Rameau (1968)). Más información sobre Diderot en España se encuentra en F. Lafarga (1979).

9. Bien claramente por cierto lo expresa el abate Andrés en Origen, progresos y estado actual de toda la literatura (Madrid, Sancha, 1784-1806, 10 vols.):

«Pero considerando la religión y las letras como dos cosas distintas en un todo, veo que puede un filósofo estar abandonado de Dios según los deseos de su corazón, y tener sin embargo sutil ingenio y fino discernimiento, y pensar justa y verdaderamente en las materias literarias. [...] si la erudición y el ingenio pueden separarse del libertinage e irreligión, y unirse con la piedad, como efectivamente vemos que sucede con frecuencia, no comprendo por qué no se pueda, y por mejor decir, no se deba desear el fino gusto de Voltaire, la elocuencia de Rousseau, y la erudición de Freret, antes que los talentos medianos de gran parte de sus contrarios» (vol. II, pp. 353-4) 
clandestinamente, y que su influencia fue notable en las generaciones que respaldarían más tarde la opción liberal de las Cortes de Cádiz ${ }^{10}$.

Algunos de ellos, como Saint-Lambert, nunca fueron condenados explícitamente por la Inquisición, pero sí fueron objeto del excesivo celo de algunos de los comisarios designados por el Santo Oficio para combatir la entrada de libros extranjeros perniciosos en la Península. Tal es el caso, por ejemplo, de su poema Les saisons, que fue encontrado sospechoso y confiscado, entre otros 500 libros, por el inquisidor Sánchez Bernal a los libreros franceses Decaris y Bertrand en Cádiz (Defourneaux, p. 125). Fuera de este episodio aislado, las obras de Saint-Lambert no parecen haber atraído la atención de la censura española, que autorizó por cierto a finales del XVIII la traducción de dos de sus obras ${ }^{11}$. Desconcierta en gran medida este desinterés inquisitorial por la obra de un enciclopedista, ateo y filósofo, muy próximo a los «malditos» (Voltaire, Rousseau, Diderot, etc.) y, al menos en sus orígenes, gran defensor del proceso revolucionario francés. Dos causas, posiblemente conjuntas, podrían explicar sin embargo este extraño silencio censor: la ya conocida arbitrariedad de la actuación del Santo Oficio en materia de prohibición de libros, por un lado, que retrasa hasta 1797 la condena de Lettres persanes y hasta 1804 la de Locke (Essai sur l'entendement humain), y exime -sorprendentemente- a intelectuales como Fontenelle o Buffon del veto inquisitorial, y por otro, la escasa repercusión que la figura de Saint-Lambert, inexcusable en los

10. No pocos estudios han demostrado ya el conocimiento directo que los ilustrados españoles tuvieron de los enciclopedistas franceses: Sarrailh (1979), Deforneaux (1973), Spell (1938), Herr (1971). Esteban (1988) pasa revista a las diferentes contribuciones al respecto en «Las Obras 'Ilustradas' sobre educación y su recepción en España» (pp. 135-160).

El caso particular de Rousseau es estudiado por Domergue en Tres calas en la censura dieciochesca (1981), a partir de las series de los fondos inquisitoriales. De ellos concluye que los lectores españoles del ginebrino, diseminados por todo el país, fueron bastante tempranos, aunque las causas contra ellos se agudizaron tras el fin de la Revolución francesa, lo cual indica que el entusiasmo rusoniano había crecido en esas fechas. La obra política de Rousseau fue, según las investigaciones de Domergue, la que tuvo mejor acogida en España, especialmente el Emilio y el Contrato social (pp. 43-67). Spell (1938) ofrece, en su ya clásico estudio sobre Rousseau, extensa información sobre la temprana acogida de sus ideas en España e Hispanoamérica.

Respecto a Voltaire, Domergue señala que la mayoría de las causas por libros prohibidos estudiadas, contienen menciones a este autor, superiores en número incluso a las referencias a Rousseau. (p. 52) Por su parte, Francisco Lafarga (1982), quien ha estudiado prolijamente la recepción de Voltaire en España, indica que, de acuerdo con lo que muestran las historias literarias de la época - especialmente la de Luzán y la de Juan Andrés- los periódicos de fines del XVIII, los fondos de las bibliotecas de los eruditos españoles y de las instituciones públicas, y las numerosas cartas en las que se hace referencia, elogiándolo o criticándolo, al patriarca de Ferney, la presencia subterránea del Voltaire ideólogo en la España del setecientos fue mucho mayor de lo que sus traducciones dramáticas a nuestro idioma permiten suponer.

11. Estas obras son, como veremos más adelante, Sara $T h * * *$ y Colección de cuentos morales. 
círculos eruditos de la Francia dieciochesca, podría haber alcanzado por contra en nuestro país, eclipsada quizá por los «grandes» ideólogos como Voltaire, etc .

Destaca de Jean-François de Saint-Lambert (1716-1803) su condición de noble, militar ${ }^{12}$ y a la vez liberal, con limitados recursos económicos pero una gran capacidad para relacionarse en los círculos la alta sociedad intelectual de su tiempo. Su amistad con Madame de Graffigny ${ }^{13}$ le abrió las puertas de los salones de la capital, y sus romances posteriores con algunas damas próximas a los círculos literarios y filosóficos, como madame de Boufflers ${ }^{14}$, madame du Châtelet ${ }^{15}$ o madame d'Houdetot ${ }^{16}$, le brindaron el acceso a los ídolos de la juventud liberal de mitad de siglo, como Voltaire o

12. En 1740, Saint-Lambert era lugarteniente en el regimiento de «Gardes Lorraines» del ducado de Lorena. Ya como capitán, combatió al servicio del rey de Francia en la campaña de Cerdeña (1744) y como ayudante de general en las de Menorca (1756) y Westfalia (1757). Su carrera militar terminó en 1766, con la muerte del duque de Lorena Stanislas Leszczynski, y a partir de 1775 fue nombrado gobernador del castillo de Joinville por Philippe d'Orleans. El ensayo más completo sobre la vida y la obra de Saint-Lambert es el de R. Poirier, Jean-François de Saint-Lambert (1716-1803). Sa vie, son oeuvre, publicado en 2001.

13. Françoise d'Isembourg d'Happoncourt, madame de Graffigny, fue quien le presentó por vez primera a Voltaire en 1735, cuando Saint-Lambert era un joven aspirante a poeta de diecinueve años y ella no había aún triunfado con Lettres péruviennes (1747) y su comedia sentimental Cénie (1750). Voltaire, que por entonces trabajaba con Madame de Graffigny en la traducción de Newton, leyó el poema «Le soir» de Saint-Lambert y contestó con unos versos en los que mostraba su admiración por el joven poeta. Fue Madame de Graffigny quien introdujo a Saint-Lambert en los salones de París después de la escandalosa muerte de Madame de Châtelet (ver nota 16).

14. Marie-Catherine de Boufflers, viuda del marqués de Remiencourt, era dama de palacio en la corte de Stanislas Leszczynski, duque de la Lorena desde 1737. Fue una de las tres mujeres a las que Saint-Lambert amó verdaderamente en su vida - siendo las otras dos Madame du Châtelet y Madame d'Houdetot-, aunque hubo de compartir sus favores con otros pretendientes, entre ellos el propio duque Stanislav.

15. La apasionada relación amorosa entre Emilie le Tonnelier de Breteuil, marquise du Châtelet-Lomont, y Saint-Lambert duró un año y medio (febrero 1748-septiembre 1749), tiempo durante el cual la dama repartió sus favores entre el escritor y Voltaire, con el consentimiento de ambos. En ese periodo quedó encinta, y falleció a consecuencias del alumbramiento en 1749.

16. La relación de Saint-Lambert con madame d'Houdetot fue sin duda la más intensa -y también la más sorprendente- de las tres. Elisabeth d'Houdetot tenía 23 años en 1751, cuando se encontró con Saint-Lambert en casa de su cuñada, Madame d'Epinay. Se había casado por conveniencia con el Conde d'Houdetot y su marido, enamorado de otra mujer, la había relegado a su castillo de Normandía. Saint-Lambert fue su mentor, su amante y su amigo durante cincuenta y dos años, en los cuales la aconsejó en sus relaciones, en sus lecturas e incluso en la educación de sus hijos. Ella fue la causa del final de la amistad entre Saint-Lambert y Rousseau, que aprovechó las ausencias militares del primero en 1756-7 para aproximarse a la joven. La infidelidad de madame d'Houdetot terminó con la ruptura entre Rousseau y el «bloque» enciclopedista, defensor de Saint-Lambert, quien reforzó sus lazos de unión con la dama. En 1793, el Conde d'Houdetot regresó de nuevo al domicilio conyugal, donde Saint-Lambert estaba instalado desde hacía cuarenta años, y los tres convivieron en él hasta la muerte del poeta en 1803. 
Rousseau ${ }^{17}$, de quienes Saint-Lambert fue amigo y también rival sentimental. Sus ideas materialistas, teñidas de un vago deísmo de cara a la galería, lo acercaron a personajes como Helvétius o Diderot, quien lo integró en su proyecto enciclopedista, en el que Saint-Lambert colaboró con trece artículos que publicó anónimamente ${ }^{18}$. Como los escritores anteriores, fue uno de los «eclécticos» -tal como los designaba Diderot- reunidos en torno a la figura del barón D'Holbach ${ }^{19}$, en cuya residencia compartió conversación y filosofía con Marmontel, Raynal, Rousseau, Duclos, Suard, y también, aunque de paso, con Hume, Franklin, Sterne, Shelburne y Garrick.

Formado en las ideas de Locke, Fontenelle y Condillac, a quien conoció por cierto en casa del barón D’Holbach, fue defensor de la moral natural y manifestó en diversas ocasiones un espíritu profundamente anticlerical. Su gran obra de pensamiento en la que trabajó durante cuarenta y cinco años, Oeuvres philosophiques, no es sino un tratado de moral laica, que prescinde explícitamente de la metafísica religiosa para prescribir una virtud y una felicidad basadas en la naturaleza y adecuadamente guiadas por la filosofía ${ }^{20}$. En consonancia con su talante liberal, defensor de los desfavorecidos, Saint-Lambert sustentó en sus escritos las ideas de los fisiócratas ${ }^{21}$ acerca de la necesidad de un gobierno justo que, repartiendo

17. Hasta 1757 -fecha del episodio con madame d'Houdetot (ver nota anterior)-, Saint-Lambert y Rousseau fueron buenos amigos, a pesar de que ciertas diferencias de orden metafísico -SaintLambert hacía gala de ideas materialistas y se había declarado ateo en las reuniones privadas- los enfrentaban en el ámbito filosófico. Fue Rousseau quien le presentó a Diderot, de quien era amigo desde 1742.

18. La amistad entre Saint-Lambert y Diderot data de 1752, época en la que este último estaba consagrado a la confección de la Enciclopedia, cuya dirección compartía con D'Alembert. El primer volumen apareció en junio de 1751 con una lista honorífica de 1431 suscriptores. Los artículos que Saint-Lambert escribió para el proyecto de su amigo fueron los siguientes (todos ellos escritos entre 1756 y 1765, y recogidos posteriormente en sus Oeuvres philosophiques): Fantaisie, Familiarité, Fragilité, Frivolité, Génie, Honnête, Honneur, Intérêt, Législateur, Louange, Luxe, Manières, Transfuge.

19. La casa que poseía el barón de Holbach en Granval sur la Marne, con una biblioteca de 3000 volúmenes, fue el lugar de encuentro de los «eclécticos», una veintena de hombres de letras que se reunían dos veces por semana para dialogar sobre todos aquellos temas que se consideraban «tabú» en otros salones, como la religión, la filosofía o el gobierno.

20. Oeuvres philosophiques se publicó tardíamente, tras la Revolución, en el año IX del nuevo calendario. Comprende seis volúmenes: I. Discours préliminaire. Analyse de l' homme. Analyse de la femme. De la raison ou Ponthiamas. II. Le Cathéchisme Universel. III. Commentaires sur le Catéchisme. IV. Analyse historique de la société. V. Essai sur la vie et les ouvrages de milord Bolingbroke. Essai sur la vie d'Helvétius. Les deux amis, conte iroquois. VI. Les mémoires pour servir la vie du maréchal de Beauvau. Les articles de l'Encyclopédie. Deux discours prononcés à l'Académie.

21. La llamada «Escuela fisiocrática» defendía la vida natural y el retorno de la nobleza a la existencia campestre. Esta escuela surge a mediados del s. XVIII en Francia como respuesta a la deficiente 
igualitariamente los impuestos y estimulando el comercio interior, frenara el abandono progresivo de las zonas rurales. Fue un gran admirador del proceso independentista norteamericano, y aunque la Revolución Francesa lo sorprendió en una edad ya avanzada, cuando ya casi todos los representantes de su generación habían fallecido (Voltaire y Rousseau en 1778, Diderot en 1784, D'Alembert en 1783, D'Holbach en el mismo 1789), Saint-Lambert mostró en los comienzos del movimiento un vivo entusiasmo por sus principios teóricos, fervor que los cruentos sucesos de finales de 1789, incluyendo los ultrajes a la familia real, acabarían transformando en un alejamiento físico y espiritual del proceso revolucionario.

Como escritor, fue especialmente renombrado por su poema largo «Les saisons», que publicó tardíamente en $1769^{22}$, cuando ya se había forjado una reputación como filósofo y poeta haciendo circular sus textos. A pesar de las severas críticas que el poema obtuvo por parte de algunos de sus contemporáneos - del clan antifilosófico, desde luego, pero también de algunos escritores «moderados» como Diderot ${ }^{23}$-, lo cierto es que los incondicionales de Saint-Lambert -Voltaire y los fisiócratas- alabaron encomiásticamente la forma en que el poeta había logrado combinar, en cada uno de los cuatro cantos que articulan los más de 3000 versos del poema, la descripción lírica de las estaciones propia de la poesía campestre con la reflexión filosófica sobre el amor a la naturaleza que se desarrollaba en determinados círculos del pensamiento de su tiempo ${ }^{24}$.

situación económica en la que se encontraba el país, cada vez más rezagado respecto a Inglaterra, y así, en 1757, un grupo de intelectuales liderado por François Quesnay propone por primera vez un esquema coherente del funcionamiento del sistema económico basado en la existencia de un orden natural para todas las cosas, incluyendo la sociedad y el sistema económico. Los componentes de la Escuela trabajaron muy unidos, actuando en cierta forma como una secta o un grupo de presión, y obtuvieron rápidamente reconocimiento social -gracias a su pertenencia a la alta sociedad-, protección de miembros señalados de la Corte-como Mme. Pompadour-, capacidad financiera y acceso a medios de comunicación. Su momento de máxima influencia fue cuando Turgot ocupó el cargo de Contrôleur général, de 1774 a 1776. La caída política de éste y la debacle económica y social del país acabaron con el prestigio de los fisiócratas, a pesar de lo cual su influencia intelectual sobre toda la escuela clásica fue notable, contribuyendo al abandono de la doctrina mercantilista y a la difusión del liberalismo.

22. El poema aparece precedido de un «Discours sur la poésie» en una edición publicada en Ámsterdam (1769) que recoge, además, L’Abénaki, Sara Th***, Ziméo, Pièces fugitives y Fables orientales.

23. De hecho, en el número del 15 de febrero de 1769 de Correspondance littéraire, philosophique et critique de Grimm y Diderot, este último escribe unas «observaciones» al poema de Saint-Lambert bastante poco benévolas, ratificadas por las del propio Grimm en nota a pie de página (pp. 158173).

24. Ver las referencias a la «Escuela fisiocrática» en la nota 22. Así se refiere Voltaire al poema de Saint-Lambert en su Précis du siècle de Louis XIV: «La France serait aujourd'hui sans gloire dans ce genre [las letras] sans un petit nombre d'ouvrages de génie, tels que le poème des Quatre 
El desarrollo narrativo de este mismo motivo -la proximidad a la naturaleza, la felicidad que se destila del «sentir natural» ajeno a la contaminación propia de la sociedad civilizada, la fuerza y la belleza de las pasiones puras- aparece en las cuatro únicas novelas cortas que escribió Saint-Lambert: Sara Th*** (1765), L'Abénaki y Ziméo (aparecidas ambas en 1769, e incluidas, junto con Sara Th*** en la edición de Les saisons aparecida ese año en Amsterdam), y Les deux amis, conte iroquois (1770). Todas ellas poseen elementos en común, como el planteamiento novelesco de asuntos de actualidad en su tiempo y de obligada discusión entre los filósofos (el esclavismo en Ziméo, las cualidades humanas del buen salvaje en L'Abénaki y Les deux amis, la felicidad del matrimonio por amor y no sometido a las constricciones de la sociedad urbana en Sara $T h^{* * *}$ ) o el hecho de que ninguna de ellas tenga como escenario el suelo francés (la accción de Ziméo sucede en Jamaica, L'Abénaki y Les deux amis se ambientan en América del Norte, y Sara Th*** en Escocia). Sólo Sara Th***, sin embargo, prescinde del exotismo americanista de los otros relatos -en perfecta consonancia con la tendencia propia de su tiempo ${ }^{25}$ - para centrar la reflexión en un ámbito geográfico y cultural próximo al lector, como es la campiña escocesa, y en un asunto propio de las relaciones sociales de la «civilización» europea de su tiempo: la felicidad de los matrimonios desiguales en origen y fortuna, pero nacidos de las rectas pasiones e iluminados por la bondad natural de la vida campestre.

Aunque la historia de $\operatorname{Sara} T h * * *$ no tuvo muy buena acogida por parte de la crítica francesa ${ }^{26}$, lo cierto es que tras la publicación de Les saisons

saisons et le cinquième chapitre de Bélisaire, s'il est permis de mettre la prose à côté de la plus elegante poésie»(citado por Durozoir en Oeuvres complètes de Voltaire en CDRom, 2006).

25. Recordemos, por citar obras pertenecientes a tres momentos diferentes, Oroonoko (1688) de Aphra Behn, Lettres péruviennes (1747) de Mme. de Graffigny o Les Incas ou la destruction de l'empire du Pérou (1777) de Marmontel.

26. En su Correspondance littéraire del 1 de septiembre de 1765, Grimm le hace por cierto una crítica demoledora. La tacha de «folletito mediocre», señalando la falta de adecuación de la extensión y el tipo de novela que elige el autor a la gravedad del asunto que trata (el matrimonio desigual de una joven de buena familia y su criado), que podría más bien ser objeto de una de esas grandes novelas de heroínas sensibles y virtuosas, arrastradas por una imaginación demasiado viva y una pasión fatal que las obliga a redimirse por el sacrificio. Echa en falta Grimm más altura moral y fuerza pasional en el personaje de Sara, y menos intelectualidad en el del sirviente Philips, tachándolos a ambos de «razonadores insoportables» sin parecido ninguno con la realidad. Denuncia también lo ficticio de la pintura idílica que Saint-Lambert ofrece de las relaciones entre señores y subordinados en la granja de los Philips, y termina insistiendo en la falta general de naturalidad de la novelita, así como en la escasa novedad de las reflexiones que en ella se recogen.

Unos días más tarde, Grimm publica en su periódico unas «Aclaraciones sobre la verdadera historia de Sara $T h^{* * *} »$, en las que, haciendo gala de la fina ironía que lo caracteriza, declara haber tenido conocimiento de los hechos reales que sirvieron de inspiración a Saint-Lambert para contar 
y de las obras que la acompañan en la edición de $1769^{27}$, Jean-François de Saint-Lambert se convirtió en un escritor conocido por el público francés y bien considerado por las instituciones literarias (no en vano obtuvo el sillón número 10 de la Academia francesa en 1770). En la España dieciochesca, sin embargo, su eco -al menos en lo tocante a los textos filosóficos- es más bien limitado ${ }^{28}$, aunque sus obras narrativas despiertan cierto interés entre los traductores y traductoras de nuestro país. Ya hemos señalado que en 1795, María Antonia de Río y Arnedo vierte al español la novela breve $\operatorname{Sara} T h^{* * *}$, que había aparecido el 15 de agosto de 1765 en la Gazette de l'Europe, y había sido recogida posteriormente junto con otras piezas narrativas del autor en la edición de Les saisons aparecida en 1769 en Ámsterdam.

Un año después de la aparición de Sara $T h^{* * *}$ en español, el impresor y traductor ilustrado Francisco de Tójar, siguiendo la moda de cuentos y relatos breves de carácter sentimental e ingrediente exótico, edita en forma de volumen -y posiblemente traduce también- algunos de los relatos de Saint-Lambert recopilados en la edición holandesa de 1769: Colección de cuentos morales que contiene el Zimeo, novela americana, las Fábulas orientales y el Abenaki ${ }^{29}$. Como bien señala el editor de la recopilación de Tójar, Joaquín Álvarez Barrientos, los cuentos de Saint-Lambert encajan a la perfección en el ideario del impresor salmantino, ilustrado inquieto

la historia de los amores entre Sara y su criado Philips. Explica Grimm que la verdadera «Sara» sería una solterona de buena familia encaprichada de su lacayo, con el que habría contraído matrimonio; que ambos vivirían en realidad en Londres rodeados del desprecio social merecido, y que la dama, maltratada por su esposo, se habría convencido de sobra del error de seguir ciegamente las propias inclinaciones: «Si tuviéramos un Fielding en Francia», se burla Grimm, «haría una parodia excelente de la novelita de M. de Saint-Lambert, mostrando el verdadero cuadro. Sería entonces el padre quien hablaría, quejándose de la mala fe con la cual el autor de la novelita ha expuesto los hechos. Esta obra podría estar repleta de alegría y de un cierto aire jocoso» (Correspondance Littéraire, la traducción es mía).

27. Ver nota 23.

28. Ya hemos señalado más arriba que las obras filosóficas de Saint-Lambert no se encuentran entre los textos prohibidos por la censura inquisitorial, y tampoco se traducen en el período que estudiamos. Sólo una parte de sus Oeuvres philosophiques, le Catéchisme Universel, se vierte en 1820 con el título: Catecismo Universal. Preceptos morales y examen de sí mismo, siendo el traductor Manuel Díaz Moreno. Por otro lado, sabemos que Les saisons tuvo notable influencia en algunos poetas españoles, como bien muestra Carnero (2000) para la poesía filosófica de Meléndez Valdés, en especial en su tratamiento de la naturaleza, cuyas deudas con el poema de Saint-Lambert son evidentes.

29. Los reedita actualmente Joaquín Álvarez Barrientos, que indica en su Introducción que El abenaki y otras fábulas breves habían aparecido ya en el Semanario de Salamanca entre 1795 y 1796, fechas en las que Tójar se hallaba al frente del periódico como impresor. La Colección de cuentos morales tuvo segunda edición en la imprenta salmantina de Tójar en 1803, con la adición del relato de Florian Sélico, novela africana (Álvarez Barrientos, 2002, p. 23) 
y reformista, a quien le debió de fascinar el mensaje humanitarista de los cuentos del escritor francés, impregnados de valores virtuosos y sensibles y de nuevos modelos de conducta (Álvarez Barrientos, 2002, p. 48). Por otro lado, Tójar era ya, en las fechas en las que edita la traducción de SaintLambert, un impresor experto (Álvarez Barrientos, 1995, pp. 25-31), que partía del éxito editorial de la versión de Sara Th*** de M ${ }^{\mathrm{a}}$ Antonia de Río, y que continuaría a posteriori nacionalizando textos extranjeros de mayor o menor extensión pero similar línea ideológica ${ }^{30}$, de forma que su versión de los Cuentos morales se inscribe en una coherente trayectoria personal, editorial y literaria.

El caso de la traducción de Sara $T h^{* * *}$ es, sin embargo, sustancialmente diferente, no sólo por el hecho evidente de su autoría femenina, sino también por la novedad del proyecto -era, como hemos señalado, la primera versión española de una obra de Saint-Lambert-, por las particulares señas de identidad de su autor original -miembro del clan enciclopedista, antirreligioso y amigo de la causa revolucionaria-, y por los mismos valores -moral natural, espíritu laico, ilustración femenina, triunfo del individuo sobre las constricciones sociales- que la obra propugna y que, como veremos, la traductora trata a toda costa de maquillar en su versión de la misma.

\section{María Antonia de Río y su traducción de $S_{A R A} T_{H}^{* * *}$}

A la luz de las obras que con la firma de María Antonia de Río han llegado hasta nosotros, la traducción de Sara $T h^{* * *}$ parece constituir el primer ejercicio literario de la autora, quien contaba tan sólo con veinte años en 1795, cuando la obra se publicó ${ }^{31}$. Tras ésta, María Antonia de Río sólo volvería a firmar una traducción más, las Cartas de Madama de Montier de Madame Le Prince de Beaumont, publicadas un año después, en 1796.

Si consideramos que Jeanne-Marie Le Prince de Beaumont era sobradamente conocida en España por el talante educativo y cristiano de sus obras, y que varias de ellas ya habían sido publicadas en España con notable éxito ${ }^{32}$, la elección por parte de la traductora de este segundo texto

30. Algunos de los textos que edita Tójar son las Nuevas novelas de Florian, Oderay, Atala, Pablo y Virginia, Zadig, Luisa o la cabaña en el valle, y también La filósofa por amor (Álvarez Barrientos, 2002).

31. La primera edición de la obra se publicó en la imprenta de José López, en 1795. No he podido encontrar ejemplar de esta edición, así que cito por la segunda, que es de 1805, y que se imprime en Valencia, en la oficina de Miguel Estevan.

32. Es el caso, por ejemplo, de los textos educativos Conversaciones familiares de doctrina cristiana (1773), Almacén y biblioteca completa de los niños (1778) y Almacén de las señoritas adoles- 
se explica con bastante facilidad. Nada que ver, sin embargo, la pedagogía bastante convencional y las posiciones «antifilosóficas» de la autora francesa en materia de comportamiento y moral religiosa, con las de su contemporáneo Saint-Lambert. ¿Qué razones, entonces, pudieron empujar a una jovencísima María Antonia de Río a traducir una novela como Sara $T h^{* * *}$, bastante alejada de la narrativa pedagógico-moral que cultivaba la mayor parte de las escritoras de su tiempo? ¿Por qué tomar como primer ejercicio literario una obra de un filósofo sensista y materialista, que obligaba a la autora a intervenir constantemente sobre el texto para adecuarlo a la corrección ideológica y religiosa impuesta por las instancias censoras pertinentes?

Un aliciente para su elección debió de ser sin duda la breve extensión de la novela (apenas cuarenta páginas en el original ${ }^{33}$ ), cuya traducción al castellano -según confiesa la propia autora en la «Protesta de la traductora que puede servir de prólogo»- le mandaron «para que se exercitara en el arte de traducir, tan difícil como provechoso» (s.p.). No podemos, desde luego, tomar al pie de la letra esta confesión de obediencia a mandato ajeno como motivación de su actividad literaria, frecuente, como ya sabemos, en los prólogos, prefacios y demás escritos con los que las traductoras dieciochescas presentan sus versiones ${ }^{34}$. Por ello, más que en este habitual recurso para ganarse la benevolencia de los lectores -y de los censores-, conviene buscar las razones de la singular elección de $\mathrm{M}^{\mathrm{a}}$ Antonia de Río en los escasos datos que sobre ella tenemos y, sobre todo, en el contenido de la novela que traduce.

Abulense de nacimiento, María Antonia de Río (Arévalo, 1775-Arequipa, 1815) perteneció a una familia castellana distinguida, en la que había recibido, según testimonio de su futuro esposo, una educación poco habitual en una mujer, en la que se incluía la lectura en francés de textos

centes (1779-1780), la obra religiosa La devoción ilustrada (1782) y la novela Memorias de la baronesa de Bateville o la viuda perfecta (1795). Otras obras de Mme. Le Prince de Beaumont, a quien no afectó al prohibición de 1799, fueron publicadas después de la traducción de $\mathrm{M}^{\mathrm{a}}$ Antonia de Río: Cuentos morales y Nuevos cuentos morales (1797), La nueva Clarisa (1797) y Cartas de Emeranza a Lucía (1807). En 1790, sin embargo, a Cayetana de la Cerda le había sido denegada la licencia para publicar la traducción de Las americanas, o prueba de la religión por la razón natural y, por más que peleó en defensa de su versión, el expediente fue finalmente sobreseído en 1804. Sobre la presencia de las escritoras francesas en la España del XVIII, y en particular sobre la traducción que $\mathrm{M}^{\mathrm{a}}$ Antonia de Río hace de Mme. Le Prince de Beaumont, ver Bolufer (2002).

33. Todas las referencias al texto francés de Saint-Lambert son de la citada edición de Ámsterdam (1769).

34. De hecho, es bastante habitual, por no decir casi de obligado cumplimiento, incluir en los textos que acompañan a las traducciones firmadas por mujeres, todo género de excusas y peticiones de indulgencia para su labor literaria, a modo de justificación a posteriori para lo que podría considerarse una inapropiada intromisión femenina en el mundo de las letras (Zorrozua, p. 135-194) 
didácticos y novelas educativas ${ }^{35}$. En Madrid vivió con su madre viuda, y allí fue donde publicó, entre 1795 y 1796, sus dos únicas traducciones largas, antes de contraer matrimonio a la edad de veintitrés años con José Agustín de Ussoz y Mozi, hijo de un oficial mayor de la Contaduría General de Indias y graduado en leyes (Rípodas, 186-7). Al haber obtenido Ussoz una plaza de oidor en el Tribunal de Charcas del Virreinato del Río de la Plata, el mismo año de su enlace, 1798, parten hacia Chuquisaca, donde llevarán durante los siguientes doce años una vida cómoda y tranquila, con un estatus social elevado. Desde su matrimonio, del que nacen cuatro hijos, María Antonia de Río no vuelve nunca más a publicar ningún ejercicio «mayor» de traducción, pero continúa leyendo en la nutrida biblioteca familiar, e incluso escribiendo. De hecho, dos pequeñas traducciones de la autora extraídas, según ella misma afirma, del «retrato de una señora respetable» realizado por un autor francés, se publican en un periódico de la capital porteña, el Telégrafo Mercantil, entre 1801 y 1802, bajo el seudónimo «La amante de su patria» (Rípodas, 190). Los testimonios de la época la muestran como una mujer sociable y religiosa, bien avenida con su marido, quien se preocupa solícitamente por su salud un tanto enfermiza; también aparece como una lectora empedernida, ardiente defensora de un modelo de mujer familiar, instruida y virtuosa que ella no siempre cumple, interviniendo públicamente en la vida política de su marido hasta donde su género se lo permite. Ambos, $\mathrm{M}^{\mathrm{a}}$ Antonia y Ussoz, se muestran leales a ultranza a Fernando VII en los años más difíciles del virreinato, y la posición política de Ussoz -que $\mathrm{M}^{\mathrm{a}}$ Antonia de Río no duda en apoyar más allá del ámbito doméstico- y de los otros oidores del Tribunal de Charcas contra el presidente de la audiencia, García Pizarro, les vale la enemistad del general Goyeneche, enviado por la Junta de Sevilla pero afín a la infanta Carlota, y finalmente el destierro en 1810. Cinco años de penurias económicas, desprecios sociales, enfermedad y continuos cambios de escenario (Oruro, Sicasica, Caracato, La Paz, Paria, Cochabamba, y al fin Arequipa), agravados por las tensiones políticas y la incertidumbre sobre el proceso revolucionario, median entre la fecha del destierro y la del fallecimiento de $\mathrm{M}^{\mathrm{a}}$ Antonia de Río, que tiene lugar en Arequipa en los primeros meses de 1815.

35. Hasta el momento, el único trabajo que ofrece datos biográficos sobre María Antonia del Río es el de Daisy Rípodas (1993). De su etapa española, sólo sabemos lo que recoge su partida de bautismo y algunas breves referencias extraídas de las cartas posteriores de su marido, José Agustín de Ussoz (Rípodas, pp. 174-5). La mayor parte de la información que sobre ella ofrece Rípodas es de la etapa americana de la autora tras su matrimonio con Ussoz, de quien, al ocupar el cargo de oidor en el tribunal de Charcas, se conservan bastantes datos que permiten reconstruir también la vida de su esposa. 
De las continuas -y a veces sorprendentes- referencias a María Antonia que Rípodas extrae de los documentos de la etapa americana de Ussoz, se deduce que, aunque al llegar a la colonia abandonara las incipientes pretensiones literarias que había mostrado en la metrópoli para acompañar a su marido en sus obligaciones sociales, la autora no se ajustaba en absoluto al patrón de reclusión doméstica y femenina docilidad que cabría esperar de una esposa de la época ${ }^{36}$. Al contrario, su carácter fuerte y su lealtad a la opción política de Ussoz, la llevaron a significarse como «oidora» consorte en la vida publica de La Plata, y muy especialmente durante los acontecimientos políticos que condujeron a su destierro. No resulta extraño que la rebeldía que muestra en su madurez ante los modelos de conducta preestablecidos ya diese sus primeros indicios en Madrid en esas aspiraciones literarias juveniles, poco frecuentes entre las de su género, de las que ella hace gala con femenina modestia en el Prólogo a las Cartas de Madama de Montier:

\begin{abstract}
En la novela inglesa Sara Th***, que tuve el honor de dar a la prensa pocos meses ha, me protesté novicia en el arte de traducir, conque diciendo ahora que desde entonces acá apenas han pasado cinco meses, digo lo bastante para que se entienda que no podré aún ser muy maestra. De la benigna acogida que experimentó del público aquella mi primera traducción, nace la esperanza que esta segunda tiene de no ser peor recibida, y aun cuando no tuviera otra circunstancia que ser obra de la respetable Madama de Beaumont, tenía todo lo que se necesita para que las gentes de gusto la lean con ansia [...] Detesto una y mil veces aun la sola idea de acometer empresas que exceden sobre manera la debilidad de mis talentos (pp. 3-4).
\end{abstract}

Su elección de Sara Th*** como primer ejercicio literario se explica también mucho mejor a la vista de ese carácter inquieto de la autora, un tanto díscolo ante los estereotipos, que la lleva a fijar su interés en una narración impregnada de consideraciones filosóficas sobre las prioridades vitales, sobre el amor -en una dimensión bastante poco evangélica- y sobre la felicidad, y cuya protagonista es por añadidura una mujer ilustrada, de criterio independiente e intachable moral.

36. Recoge Rípodas en su trabajo documentación con ejemplos sobrados de las intervenciones públicas de $\mathrm{M}^{\mathrm{a}}$ Antonia: sus enfrentamientos con el Presidente García de León y el Arzobispo, sus incitaciones públicas a la rebeldía popular el 25 de mayo de 1809, su papel de mensajera durante el encarcelamiento de su marido, su fracasado intento de entrar en prisión disfrazada de hombre, la defensa de su marido contra las acusaciones de Goyeneche, y un largo etcétera de episodios variados que demuestran no sólo las buenas relaciones del matrimonio, sino también el respeto que Ussoz mostraba ante el criterio de María Antonia y su acusada personalidad, poco común entre las mujeres de su tiempo (pp. 92-104). 
En su novelita «inglesa», Saint-Lambert narra la historia de una joven huérfana de alta alcurnia, Sara Th..., que renuncia a título y fortuna por el amor de un sirviente escocés. Tras contraer matrimonio y fingir la muerte de Sara para evitar el escarnio social, ambos se retiran a la campiña escocesa y se consagran en cuerpo y alma al cuidado de la granja y de los hijos, formando con sus empleados una gran familia feliz, rodeados de la paz y la armonía que sólo una existencia alejada de los males de la civilización puede garantizar. En ese estado de idílica placidez los encuentra el narrador, un joven inquieto de buena familia que, después de recorrer vanamente el mundo en pos de la razón y la felicidad, recibe el encargo paterno de hacerse cargo de la hacienda que poseen en Escocia, y que habrá de pasar a sus manos en el momento en que encuentre esposa. Profundamente impresionado por los valores que percibe en el estilo de vida que el matrimonio Philips ha conseguido crear a su alrededor, y muy especialmente por Sara, quien desdice con su formación y sus elevadas virtudes el modelo de campesina que el narrador posee, éste descubre finalmente la verdadera identidad de la muchacha, que resulta ser una pariente a la que él amó en su juventud y cuyos bienes recibió en herencia tras anunciarse públicamente su fallecimiento. Sara y Philips, felices en su autarquía campestre, rechazan de nuevo la herencia que el narrador les ofrece, y éste decide finalmente instalarse cerca del matrimonio para compartir así las bondades naturales y morales del entorno.

Aunque el argumento de la novela no aporta en sí mismo gran novedad, lo cierto es que detrás de esta inocente historia de amor y virtud, se esconden los principales ingredientes del pensamiento filosófico de su autor, que se mueve hábilmente entre la esfera de lo privado -el individuo y sus relaciones íntimas, personales, con el resto de individuos- y el ámbito de lo público -la organización de la comunidad, el modelo social, las «normas» de comportamiento - para ofrecer un modelo humano y colectivo plenamente dieciochesco.

Para empezar, la voluntad de resaltar la preeminencia del individuo -de sus afectos, de sus instintos, de sus sentimientos y de su felicidad- sobre las restricciones sociales se encuentra en la base de ese matrimonio desigual que da pie a la novela y que logra perturbar sobremanera a algunos críticos de la obra, incómodos ante la subversión del orden social que esta unión insinúa ${ }^{37}$. De hecho, es la pasión amorosa -casta, pero arrolladora- de Sara hacia Philips, la que actúa como motor de la historia e impulsa a la protagonista, una vez disuelto el probable obstáculo de la autoridad competente con el oportuno fallecimiento del padre, a saltar por encima de los obstáculos sociales para, renunciando a fortuna y posición social, legitimar su amor

37. Ver nota 26. 
con el lazo conyugal. La fuerza de la naturaleza actúa en la novela como contrapunto de la represión social -representada por aquellos ante quienes Sara se ve obligada a fingir su muerte para preservar el buen nombre familiar- y a la vez en armoniosa sintonía con el ejercicio de la razón. La pasión amorosa de Sara y Philips no se muestra jamás desordenada, ni vulnera en ningún momento los límites del decoro; antes bien, es un amor razonable y virtuoso, que incluye la contención y el respeto mutuo; así, Philips nunca declara a Sara un amor que sabe inoportuno, y trata en reiteradas ocasiones de disuadir a la joven de sus planes de renuncia, mientras que ella emplea su modélico sentido común para buscar la solución más acertada y decorosa, pero también más acorde con el inapelable dictado de la naturaleza.

Ese arduo ten con ten entre razón y sentimiento requiere en quienes lo ejercitan un grado de «ilustración» ejemplar, cuyos límites se encarga de extender la novela más allá de los círculos que habitualmente lo disfrutan, insistiendo en las lecturas y en la altura intelectual de los dos granjeros. De hecho, en la biblioteca de ambos, contrariamente a lo que espera el narrador, se acumulan los tratados técnicos sobre agricultura, mecánica y medicina, las obras de los enciclopedistas (Montaigne, Diderot, Voltaire) y de los filósofos ingleses (Lord Shaftesbury, Hutcheson), las novelas de Richardson, además una ingente cantidad de lírica campestre (desde los clásicos Virgilio, Teócrito, etc., a los grandes poetas del setecientos como Dryden, Cowley, Philips, Thomson) e incluso algún texto poético poco común como el Praedium Rusticum del jesuita Vanières. No en vano Sara ha sido educada, por un padre amante de la filosofía y las letras, en la sensibilidad hacia las bellezas del arte y la naturaleza, en los placeres de la imaginación y en el gusto por la literatura. Por su parte, Philips, que ya presentaba una vocación innata por el estudio y la lectura, recibió, al ser encargado del cuidado de la biblioteca por el padre de Sara, el espaldarazo necesario para perseverar en su trayectoria de «ciudadano ilustrado»e «honra de su patria» (p. 41).

Philips, el sirviente letrado y autodidacta, y Sara, la mujer ilustrada, son una excelente representación literaria de la relevancia que el proyecto educativo alcanza en la visión política de Saint-Lambert, defensor de un modelo de estado conducido por una monarquía paternalista y legisladora, capaz de liderar justamente una comunidad de ciudadanos formados e informados ${ }^{38}$. El ideal de vida campestre elegido por el matrimonio forma

38. Los artículos que Saint-Lambert publica en la Enciclopedia de Diderot dejan ver a la perfección las ideas políticas de su autor, que repite insistentemente las referencias al orden, a la comunidad, a la patria y a la virtud. El artículo «Législateur», aparecido en el noveno volumen, explica precisamente su concepto del estado ideal, gobernado por un rey sensible a las ideas de las Luces, el monarca ilustrado de los «filósofos», que es buen legislador y sabe a la vez comunicarse con su pueblo. 
parte también del modelo vital y social propuesto por el autor, y revela la influencia que recibe del pensamiento fisiocrático, desarrollado más tarde en forma lírica en el poema «Les Saisons». La felicidad que Sara y Philips obtienen en el trabajo diario, la naturalidad con la que se vuelcan en el amor conyugal y el cuidado de los hijos -con especial insistencia en la lactancia materna- sin descuidar el ejercicio intelectual, la armonía general que preside las relaciones humanas en el ámbito de la granja, las bondades del contacto con la naturaleza, etc., convierten la propiedad de los Philips en una suerte de Arcadia utópica y ejemplar, alejada de las exigencias y restricciones de la sociedad urbana, de las imposiciones del lujo y de cualquier forma de miseria moral.

Fue, probablemente, este ideal filosófico de realización personal y concordia social, impregnado de Ilustración y humanitarismo laico, el que atrajo la atención de María Antonia de Río, cuya condición de mujer letrada la colocaba en especial disposición para recibir mensajes en provecho de su propio género. El personaje de Sara Philips resultaba, en este sentido, especialmente atractivo, tanto en sus cualidades personales como en su capacidad de acción y resolución. De hecho, Sara, que posee un alma «altiva, elevada y sensible» (p. 45), y que ha sido formada por su padre en «la virtud y los placeres de la imaginación honestamente dirigida» (p. 38), en la inclinación a la Filosofía y en el «gusto y amor a las letras» (p. 39), da sobradas muestras en la novela de su capacidad de raciocinio, mostrando una pertinaz rebeldía ante las convenciones sociales de clase y de género:

Estaba yo demasiado ilustrada para no conocer las consequiencias de mi pasión: pero bien pronto no hice uso de mis luces mas que para servirla, y no para combatirla. Temía y respetaba el juicio de los hombres, pero decía: ellos no han adherido la vergüenza de los sentimientos; solté la rienda a los míos (p. 45).

Muerto el padre, la joven se dedica al cuidado de sus bienes y al estudio, desentendiéndose de la búsqueda de marido que debía preocupar a una joven huérfana y soltera, y mostrando sin ambages su disconformidad ante la obligatoria sumisión a las leyes sociales y a las costumbres, y «el poder que deben tener sobre las almas ilustradas» (p. 49). Pero la insumisión de Sara va más allá de una expresión aislada de disidencia para alcanzar a las propias decisiones de la joven sobre su destino. Así, después de rechazar tajantemente la oferta matrimonial de su primo, negándose a admitir una idea de la felicidad fundamentada en las conveniencias más que en los deseos personales, es ella quien renuncia a combatir su amor por Philips y toma la iniciativa para empujarlo a él, más prudente e indeciso que nunca, a saltar las barreras sociales. Es Sara quien convence a 
Philips, con una impecable argumentación acerca de la relevancia de la ley natural sobre las convenciones sociales ${ }^{39}$, es ella quien pergeña el plan para desaparecer juntos y organiza el destino de sus bienes, ella la que forja la «utopía» escocesa, y ella, además, la que dispone que todo ello se haga conforme a los dictados del honor y del sentido común:

Quiso aquí interrumpirme Philips, proponiéndome no nos casásemos; pero le corté la palabra y le dixe: por qué no? Por conservar mis bienes? Ellos no me hacen rica en el estado que estoy, y lo seré en el tuyo con el dote que quiero llevar (p. 61).

Es ésta por cierto la misma Sara que, después de haber dado muestras sobradas de su naturales luces -convenientemente pulidas por su esmerada educación-, su capacidad de resolución y su integridad moral, aparece también encarnando las cualidades por excelencia femeninas, como solícita cuidadora de todos los que la rodean, madre abnegada y piedra angular de un matrimonio ejemplar:

Jamás he visto unión tan deliciosa, porque rara vez sucede hallar entre dos personas las relaciones que había entre ellos: tenían el mismo grado de sensibilidad, los mismos gustos, las mismas opiniones y el mismo amor a la virtud (p. 24).

Sara es también la que cuenta al narrador la historia de su vida, y la que da voz en la novela, muy especialmente en sus últimas páginas, a la nutrida exposición ideológica de Saint-Lambert, que abarca planteamientos filosóficos generales como la felicidad, la educación, la poesía y la virtud.

La conjunción de feminidad y autonomía moral que representa Sara era sin duda lo suficientemente sugerente para atraer la atención de la traductora. También lo era, por supuesto, la propia historia de la novela, que pinta las bondades de un amor no impuesto, y legitima, con el feliz destino de sus protagonistas, una pasión contraria en gran medida a las convenciones sociales. A María Antonia de Río no podía escapársele el desajuste existente entre la propuesta de desarrollo vital de la novela de Saint-Lambert, ceñida en todo momento a los dictados de una moral natural, y los

39. «En convenirse las personas estriba la felicidad de los matrimonios: las convenciones humanas substituyeron en su lugar la conveniencia. Sabemos tú y yo cuánto respeto tienen los verdaderos sabios por estas convenciones, que mantienen el orden en las sociedades. No se debe envilecer la clase en que se ha nacido por alianzas que la opinión condena; éste es un crimen que se castiga con el menosprecio de las gentes, que aunque injusto, no sabría yo sobrellevar; ¿pero acaso se requiere posponer la ley de la naturaleza a las convenciones de la sociedad? Puede ser; pero nosotros no nos hallamos en este caso: respetemos la opinión, pero cedamos al deseo de nuestros corazones» (p. 60). 
estrechos límites que la moral religiosa española establecía en asuntos tan espinosos como la realización individual o la satisfacción de los instintos naturales, y menos aún podía habérsele pasado por alto a la autora la inconveniencia de que tales argumentos fueran planteados y defendidos en la obra por una mujer, y expuestos en nuestro idioma, además, en un texto con firma femenina.

Por ello, y a diferencia de lo que ocurre con su segunda obra, cuyo Prólogo se limita a reproducir el de Le Prince de Beaumont, $\mathbf{M}^{\mathrm{a}}$ Antonia de Río cierra la traducción de Sara $T h * * *$ con una «Protesta de la traductora que puede servir de Prólogo» que trata, precisamente, de dirigir la atención del lector hacia los elementos menos subversivos del texto de Saint-Lambert. Con gran habilidad, propone allí una lectura más bien ingenua de la intención de la novela, que describe como una «pintura de la felicidad de la vida sana y sencilla del campo, que tanto abochorna al doblez y a los placeres facticios [sic] de las ciudades», para, a continuación, emplearse a fondo en una previsora justificación o relativización de aquellos puntos susceptibles de escandalizar -o al menos desagradar- a los lectores españoles. Con la cuidadosa estrategia de buscar el reverso provechoso de cada elemento conflictivo, la autora compensa la inconveniencia del matrimonio desigual de Sara y Philips insistiendo en las virtudes morales de la joven, y justifica su incontinencia sentimental, «poco correspondiente a su nacimiento», con la naturaleza siempre virtuosa de su amor y, sobre todo, con su posterior redención a través de una vida ejemplar dedicada a hacer la felicidad de los otros, como corresponde al modelo femenino desde tiempos inmemoriales. Es interesante señalar que la autora no deja de hacer referencia en su prólogo a la religiosidad de Sara, de la que, como veremos, no hay rastro alguno en el texto original -sí, por el contrario en la versión española-, pero que serviría con toda seguridad para congraciar a los lectores y lectoras con la díscola y pasional Sara. De hecho, y siempre con el objetivo de «distraer» la atención hacia las actitudes menos ambiguas de la protagonista, la retórica de la domesticidad y de la religiosidad desplegada en las primeras líneas se complementa en el prólogo de $\mathrm{M}^{\mathrm{a}}$ Antonia de Río con el elogio del «sacrificio en vida», indicando que no puede haber mal ejemplo en los posibles yerros de Sara si se purgan con la renuncia a la vida pública y con la aceptación voluntaria de una muerte «formal», tal como en la novela ocurre. Por supuesto, no hay referencia ninguna en el prólogo de la traductora a la lección de «moral natural» que ofrece Saint-Lambert en su novelita, pasando oportunamente por alto el que la bondad de Sara, lejos de plantearse como un sacrificado camino de perfección, sea más bien el resultado de la felicidad que se obtiene al no obrar contra natura, reprimiendo absurdamente los sentimientos propios por los dictados sociales, y 
al haber recibido una educación esmerada capaz de elevar el nivel moral e intelectual de aquella que la ostenta.

El hábil ejercicio prologal de $\mathrm{M}^{\mathrm{a}}$ Antonia de Río fue bien recibido por la prensa de la época, que se hizo eco, en las reseñas aparecidas sobre la traducción, de la ejemplaridad de la obra que la autora anunciaba en su «Protesta...» ${ }^{40}$. Pero la intervención de la traductora sobre la novela de Saint-Lambert no se limita única y exclusivamente a este pequeño texto original, que desvía el sentido y la interpretación de la novela francesa, o, al menos, la aligera de su carga filosófica; siguiendo las prácticas habituales en el XVIII en la traducción de textos extranjeros (Urzainqui, 1991; Alonso Seoane, 1991; Pajares, 1996; Lafarga, 1997; Álvarez Barrientos, 1998), la propia versión de $\mathrm{M}^{\mathrm{a}}$ Antonia de Río muestra los desvelos de la autora por «aclimatar» el texto francés a la moral social y religiosa española, adaptándolo al sistema de valores nacional.

Un pequeño número de las modificaciones introducidas refleja, además de la voluntad de la autora de adaptar la novela que traduce a los usos y costumbres de la sociedad española, la exigencia de recato a la que su género la obliga. Esto explica su interés por suavizar lo explícito de ciertas descripciones, impropias a todas luces en pluma femenina, como ocurre con la imagen de Sara amamantando a su hijo y mostrando un pecho blanquísimo «que dejaba ver todo entero» en la obra de Saint-Lambert, referencia que se suprime en la versión española (p.6), o con la insinuación en el texto francés de la felicidad del matrimonio Philips al compartir su lecho conyugal, que la traductora resume en un comedido «estos felices esposos fueron a recogerse» (p. 25). El mismo afán de moderación la lleva a mitigar las referencias a la «pasión» de Sara y Philips, que se queda en el texto español en un «amor» (p. 35) más prudente, que, al contrario que en el original francés, no puede ser enteramente sentido por los amantes mientras no están casados ${ }^{41}$. En otras ocasiones, como cuando describe

40. Así ocurre en La Gaceta y el Diario de Madrid, en sendas reseñas sobre la novela aparecidas respectivamente el 4 de agosto y el 26 de septiembre de 1795, que la describen -tal como ya he citado en las primeras líneas de este trabajo- como «un modelo de desempeño de una madre de familia, un exemplo de la felicidad que produce el cumplimiento de ellas, y una pintura agradable de las delicias de la vida del campo» (pp. 828 y 1091, respectivamente). Algo similar se encuentra también en el número de marzo del Memorial Literario de 1796, que reproduce casi literalmente, como era frecuente en la época, el prólogo de la traductora.

41. «Viví dos años feliz por el placer de amar, y por el de ser amada, y menos humillada de mi amor que orgullosa de no entregarme a él sino con moderación. Era feliz; pero perdí a mi padre, y dudo si le hubiera sobrevivido sin este sentimiento que consuela de todo, y que enteramente no poseía» (pp. 45-6, la cursiva es mía).

En el original de Saint-Lambert, la última frase es exactamente la contraria: «ce sentiment qui console de tout et dont j'étois remplie» (pp. 25-26). 
las inmejorables relaciones del matrimonio Philips con sus sirvientes o el «ilustrado» proyecto educacional del padre de Sara, M $^{\mathbf{a}}$ Antonia de Río no duda en eliminar o modificar referencias inaceptables para el código social español; así, en el primero de los casos, sustituye la «igualdad» entre amos y criados de la que habla el texto original por una «armonía» (p. 17) menos susceptible de vulnerar las jerarquías sociales establecidas, mientras que en el segundo, enriquece la descripción de las cualidades inculcadas a Sara por su padre añadiendo, al entusiasmo por la virtud y a la sensibilidad ante las bellezas del arte y la naturaleza, los placeres de la imaginación «honestamente dirigida» (p. 38), menos alarmante y, por supuesto, más apropiada para la formación femenina.

Más allá de estas discretas modificaciones, lo cierto es que en lo que respecta a los acontecimientos fundamentales del relato, la versión española se muestra bastante fiel al original. No ocurre lo mismo, no obstante, con el fondo filosófico de la obra, que queda, tras las intervenciones de $\mathrm{M}^{\mathrm{a}}$ Antonia del Río, revestido de un barniz moralista cristiano poco acorde con las pretensiones de la novelita francesa. De hecho, la traductora, primeriza pero no por ello menos avezada en los recursos de la traducción nacional, no duda en añadir, suprimir y cambiar cuanto le resulta conveniente para disfrazar el espíritu laico que impregna el texto de Saint-Lambert, y para mitigar la incontinencia sentimental de Sara, potenciando la ejemplaridad de su conducta conyugal.

De hecho, si ya en la novela original de Saint-Lambert, las reticencias que el desafío de los protagonistas a las costumbres y usos sociales pudiera suscitar en los lectores eran contrarrestadas con el elogio y ponderación de la virtud de ambos, la versión española añade además constantes y explícitas referencias a su integridad moral. Al describir la afinidad espiritual de la pareja, por ejemplo, la traductora nos dice que ambos tenían «el mismo grado de sensibilidad, los mismos gustos, las mismas opiniones, y el mismo amor a la virtud» (p. 24, la cursiva es mía), frase esta última que no se halla en el original francés; igualmente, al referirse Sara a las lecturas que impulsan su búsqueda de la virtud, la traductora no duda en sustituir las novelas de Richardson que aparecen en la obra de Saint-Lambert por «buenos libros de moral» (p. 71), lo cual la obliga a reescribir todo el párrafo para adaptarlo al nuevo sujeto, y tan sólo unas líneas más adelante, en la descripción que realiza la protagonista de la educación de sus hijos, añade el texto español la necesidad de formarlos «sobre todo virtuosos» (p. 75), por encima de los principios filosóficos de la vida natural que se citan en la obra original.

En general, la mayoría de las adiciones que el texto español presenta tienen como fin convertir al matrimonio Philips en un ejemplo de piedad religiosa y fe cristiana. Su nutrida biblioteca, repleta de textos de filosofía y derecho natural en lugar de libros de devoción como el narrador espe- 
raba, es el primer objetivo de la traductora, quien, al describirla, elimina los títulos de los enciclopedistas franceses que aparecen en el original de Saint-Lambert y los sustituye por el Nuevo y el Antiguo Testamento, algunos Sermonarios y otros tantos tratados de piedad, respetando tan sólo el Predio Rústico del jesuita Vanières.

Más adelante, al referirse a las enseñanzas que Sara y Philips daban a sus trabajadores, que se limitan en el original a una apología de las bellezas naturales y de la ética del trabajo, la autora les añade de su propia cosecha el apostolado cristiano, y señala explícitamente como tema de conversación entre unos y otros el de «la bondad del Divino Criador que corresponde con tantos beneficios a la industria del hombre» (p. 19).

En otras ocasiones, el deseo de transformar a los protagonistas de la novela en devotos cristianos la lleva a suprimir en su texto referencias propias del librepensamiento de su tiempo, como la apelación de Sara a la «ley natural» para justificar y amparar el matrimonio entre señora y criado, en aras de las exigencias del amor y de la propia naturaleza:

Ici Philips voulut m'interrompre: il me proposa de ne point nous marier; je l'arrêtait et lui dit: nous manquerions a la loi de la nature et a celle des hommes qui nous demandent une posterité (p. 32).

Ello explica también el afán de la autora por encontrar a toda costa una justificación religiosa a las «luces» de las que Sara y Philips hacen gala. En virtud de ese interés, la felicidad terrena, que aparece como objetivo primordial del conocimiento y la reflexión en el original de Saint-Lambert, se encuentra supeditada en la versión española a una adecuada preparación de la vida eterna:

Ni Philips ni yo hacemos uso de nuestros conocimientos, de la filosofía de mi padre y de nuestro amor a las letras sino para asegurar nuestra felicidad temporal en este mundo, de modo que no nos hagamos indignos de gozar la infinita e interminable del otro (la cursiva es mía, p. 67).

Por eso también, donde el texto francés indica que la filosofía hace fuertes los principios, el de $\mathrm{M}^{\mathrm{a}}$ Antonia de Río apunta en su lugar a la religión como fuente única de fuerza moral:

¿Qué es lo que nos hace a Philips y a mí felices? El testimonio de nuestra conciencia, nuestro amor y los beneficios de la naturaleza. Tenemos principios, más allá de los cuales no podemos ser arrastrados por las circunstancias, y que fortificamos con la religión (p. 68, la cursiva es mía). 
Sin duda, con este esfuerzo de sustitución, supresión y adición, la autora conseguía modificar las claves interpretativas de la novela, de manera que la versión española de la historia de Sara y Philips se convertía, al menos superficialmente, de alegato filosófico en defensa de una moral natural apoyada en la exigencia de felicidad y en la satisfacción -controlada, eso sí- de los instintos, en novela ejemplar de un modelo conyugal cristiano fundamentado en el sacrificio purgatorio -la «muerte» social- de las veleidades del cuerpo y en el obligado cumplimiento de los preceptos religiosos. Nacionalizando el espíritu, laico y peligrosamente «filosófico», del texto original, $\mathrm{M}^{\mathbf{a}}$ Antonia de Río se aseguraba de que si la fama del enciclopedista Saint-Lambert precedía a la llegada de su primera novela al ámbito español, al menos el contenido de ésta en su versión patria fuera intachable en cuanto a su ejemplaridad moral y religiosa. Bajo esta fachada de pedagogía moral cristiana, la traductora apostaba en realidad por un modelo femenino vital bastante divergente del estereotipo dieciochesco, y lo hacía ofreciendo a los lectores y a las lectoras españolas un texto que postulaba la necesidad de educación de las mujeres, reconocía sus aptitudes naturales para el ejercicio de la actividad intelectual, afirmaba su capacidad para conducir autónomamente sus propios destinos y proponía para ellas pautas de comportamiento novedosas sin dinamitar sus funciones socio-sexuales ya establecidas. Las «luces» de Sara Th*** constituyen así una aportación singularmente valiosa de $\mathrm{M}^{\mathrm{a}}$ Antonia de Río y Arnedo a la Ilustración española, no sólo por su condición de traducción y, como tal, inestimable instrumento de acercamiento y contacto cultural de nuestro país con el eje del pensamiento europeo dieciochesco, sino también por alumbrar la ideología de género del cambio de siglo con modelos novedosos en el ámbito español y escasamente rastreables en la esfera literaria nacional hasta más de un siglo después. 


\section{BIBLIOGRAFÍA}

Alonso Seonne, $\mathrm{M}^{\mathrm{a}}$ José, «Adaptaciones narrativas en el siglo XVIII español. El amor desinteresado de Pablo de Olavide». En $\mathrm{M}^{\mathrm{a}} \mathrm{L}$. Donaire \& F. Lafarga, Traducción y adaptación cultural: España-Francia. Oviedo, Universidad, 1991, pp. 129-209.

Álvarez Barrientos, Joaquín, «Francisco de Tójar como impresor». En F. de Tójar, La filósofa por amor. Ed. de J. Álvarez Barrientos. Cádiz, Universidad, 1995, pp. 25-31.

—. «Traducción y novela en la España del siglo XVIII: una aproximación», en F. García Lara (ed.). I Congreso Internacional sobre novela del siglo XVIII. Almería, Universidad, 1998, pp. 9-22.

—. «Introducción» a Colección de cuentos morales (los da a luz F. de Tójar), ed. de J. Álvarez Barrientos, Universidad de Salamanca \& Universidad de Cadiz, 2002, pp. 9-53.

ANDRÉs, Juan, Origen, progresos y estado actual de toda la literatura. Madrid, Sancha, 1784-1806, vol. II.

Aragón, $\mathbf{M}^{\mathrm{a}}$ Aurora, «Traducciones de obras francesas en la Gaceta de Madrid entre 1790 y 1799». En F. Lafarga (ed.). Imágenes de Francia en las letras hispánicas. Barcelona, PPU, 1989, pp. 261-269.

Bolufer, Mónica, «Pedagogía y moral en el siglo de las luces: las escritoras francesas y su recepción en España». Revista de Historia Moderna, 20 (2002), pp. 251-292.

CARnero Arbat, Guillermo, «La oposición entre el campo y la ciudad en Meléndez Valdés», en Homenaje a José M Martínez Cachero. Vol. II. Oviedo, Universidad, 2000, pp. 357-392.

De Río y Arnedo, María Antonia, Sara Th***. Novela inglesa. Traducida del francés por Doña María Antonia de Río y Arnedo. Valencia, Oficina de Miguel Estevan, 1805.

-. Cartas de Madama de Montier. Recogidas por Madama Le Prince de Beaumont. Traducidas por María Antonia de Río y Arnedo, Madrid, D. Benito García, 1798.

Defourneaux, Marcelin, Inquisición y censura de los libros en la España del siglo XVIII, Madrid, Taurus, 1973.

Demerson, Paula de, Esbozo de biblioteca de la juventud ilustrada (1740-1808), Oviedo, Cátedra Feijoo, 1976.

Diario de Madrid. Reseña de Sara Th***. Número 269, 26 de septiembre de 1795, p. 1091.

Domergue, Luciente. Tres calas en la censura dieciochesca, Université Toulouse-Le Mirail, 1981. 
—. «Ilustración y novela en la España de Carlos IV», en Homenaje a José Antonio Maravall. Vol. I, 1985, pp. 483-498.

Esteban, León, «Las obras ilustradas sobre ‘educación’ y su recepción en España», en La educación en la Ilustración española, n. ${ }^{\circ}$ monográfico de Revista de Educación, 1988, pp. 135-160.

FranKLIN LeWIS, Elisabeth, Women Writers in the Spanish Enlightenment. The Pursuit of Hapiness, Hants, England, Burlington Vt., Ashgate, 2004.

Gaceta de Madrid. Reseña de Sara Th***. Número 62, 4 de agosto de 1795, p. 828.

García Garrosa, Ma Jesús, «Mujeres novelistas españolas en el siglo XVIII», en F. García Lara (ed.), I Congreso Internacional sobre novela del siglo XVIII, Almería, Universidad, 1998, pp. 163-176.

—. «Publicidad y venta de novelas en España a finales del siglo XVIII», Bulletin of Spanish Studies, LXXXII, 1 (2005), pp. 19-35.

Grimm, Friedrich Melchior, Correspondance littéraire, philosophique et critique de Grimm et Diderot depuis 1753 jusque'en 1790, Tome sixième (1768-1770). Paris, Chez Furne Libraire, 1829.

HERR, Richard. España y la revolución del siglo XVIII, Madrid, Aguilar, 1971.

LAFARGA, Francisco, «Notas acerca de la fortuna de Diderot en España». Anuario de Filología, 5 (1979), pp. 353-368.

—. Voltaire en España. Barcelona, Universitat, 1982.

—. «La traduccion en la España del siglo XVIII», en J.M. Santamaría et al. (eds.), Transvases culturales, literatura, cine y traducción, 2. Vitoria, Universidad del País Vasco, 1997, pp. 37-55.

Memorial Literario. Reseña de Sara Th***. Marzo 1796, pp. 390-1.

PAJARES, Eterio, «La teoría de la traducción en el siglo XVIII», Livius, 8 (1996b), pp. 165-174.

Palacios Fernández, Emilio, La mujer y las letras en la España del siglo XVIII, Madrid, Ediciones del Laberinto, 2002.

PoIrIER, Roger, Jean-François de Saint-Lambert, 1786-1803: sa vie, son oeuvre, Sarreguemines, Pierron, 2001.

Rípodas Ardanaz, Daisy, «Una ignorada escritora en la Charcas finicolonial: María Antonia del Río y Arnedo», Investigaciones y ensayos, 43 (1993), pp. 165-207.

Saint-Lambert, Jean-François de, Les saisons, poème. L'Abénaki. Sara Th***. Ziméo. Pièces fugitives. Fables orientales, Ámsterdam, 1769.

—. Oeuvres philosophiques, Paris, 1797.

- Colección de cuentos morales (los da a luz Francisco de Tójar), ed. de J. Álvarez Barrientos, Salamanca, Universidad, 2002. 
SARRAILH, Jean. La España ilustrada de la segunda mitad del siglo XVIII, Madrid, Fondo Cultura Económica, 1979.

Spell, Jefferson R, Rousseau in the Spanish World before 1833: a study in Franco-Spanish literary relations, Austin, The University of Texas Press, 1938.

Sullivan, Constance, «Las escritoras del siglo XVIII», en Iris M. Zavala (coord.), Breve historia feminista de la literatura española, Vol. IV. Barcelona, Anthropos, 1997, pp. 305-330.

Trueba, Virginia, El claroscuro de las luces. Escritoras de la Ilustración española, Barcelona, Montesinos, 2005.

URZAINQUI, Inmaculada, «Hacia una tipología de la traducción en el siglo XVIII: los horizontes del traductor», en $\mathrm{M}^{\mathrm{a}}$. L. Donaire y F. Lafarga (ed.). Traducción y adaptación cultural: España-Francia. Oviedo, Universidad, 1991, pp. 623-638.

Voltaire. Oeuvres complètes de Voltaire en CD Rom. Association Voltaire Integral, 2005.

Zorrozua Santiesteban, $\mathrm{M}^{\mathrm{a}}$ del Pilar, Escritoras de la Ilustración española (1759-1808), Bilbao, Dpto. Publicaciones Universidad Deusto, 1999 (Microforma). 